\title{
Finite element modeling of flexural behavior of reinforced concrete beams externally strengthened with CFRP sheets
}

\author{
Mahmoud Madqour, Hilal Hassan, Khaled Fawzy \\ Structural department, Zagazig University, Egypt \\ Madqour42@gmail.com https://orcid.org/0000-0002-0994-2884 \\ hilalcivil@yahoo.com https:/ /orcid.org/0000-0001-5486-5497 \\ khaled_lashen1@yahoo.com bttps:/ /orcid.org/0000-0003-2275-4025
}

\begin{abstract}
In this research, the finite element method is used to develop a numerical model to analyse the effect of the external strengthening of reinforced concrete beams by using carbon Fiber Reinforced Polymer (CFRP) sheets. A finite element model has been developed to investigate the behavior of RC beams strengthened with CFRP sheets by testing nineteen externally simple R.C. beams, tested under a four-point load setup until failure. Various CFRP systems were used to strengthen the specimens. The numerical results using the (ANSYS workbench v.19.1) were calibrated and validated with the experimental results. The research results indicate a significant improvement in the structural behavior of the specimens strengthened using CFRP sheet systems. Then the validated model investigated the effect of the width of CFRP sheets, no of layers, and CFRP size on the behavior of strengthened R.C. beams. Results of this numerical investigation show the effectiveness of increase CFRP width to improve the flexural capacity of R.C. beams. An increase in the flexural capacity up to $100 \%$ compared to the control beam.
\end{abstract}

KEYWORDS. Strengthening; Carbon fiber reinforced polymer; Deflection; ANSYS; Ultimate strength.

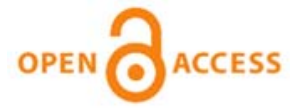

Citation. Mahmoud madqour, Hilal Hassan., Khalid Fawzi., Finite element modeling of flexural behavior of reinforced concrete beams externally strengthened with CFRP sheets, Frattura ed Integrità Strutturale, 59 (2022) 62-77.

Received: 30.08 .2021

Accepted: 30.09 .2021

Published: 01.01.2022

Copyright: (C) 2022 This is an open access article under the terms of the CC-BY 4.0, which permits unrestricted use, distribution, and reproduction in any medium, provided the original author and source are credited.

\section{INTRODUCTION}

$\mathrm{O}$ ver the past decades, (FRP) has been commonly used to repair and rehabilitate civil structures, showing signs of aging degradation and distress. (CFRP) is a brittle material that typically fails at a lower load level (i.e., horizontal crack propagation or debonding). As a result, the ultimate capacity of the reinforced concrete structural elements is challenging to achieve., Kang et al.,[1]. In the past, various researchers conducted studies on reinforced concrete beams with CFRP retrofitted in flexure, and the failure patterns were observed [2-4].

Recent research has focused on the impact of geometric factors such as length and the FRP-concrete width ratio. It has been shown that the ultimate stress for debonding increases with bonded length up to a critical bond length.

Although numerous researchers have presented results demonstrating the influence of FRP laminate width on ultimate load, these results are frequently inconsistent [5-7]. The available results in the literature are frequently contradictory. While some 
studies have indicated that average bond strength decreases with FRP width [5], others have found that bond strength increases with FRP width [8].

Travassos et al [9] suggested adding more CFRP composite at the ends of the CFRP plate to prevent premature debonding. Two approaches were offered in particular: (i) addition of more layers of rectangular CFRP sheets; and (ii) addition of more layers of CFRP sheets across the main CFRP plate.

Hasnat et al. [10] studied reinforced concrete beams strengthened by carbon-fiber-reinforced polymer sheets. A CFRP wrap (u-shape) had prevented the premature cover from debonding, increasing the final moment's efficiency. The study on reinforced concrete beams, consisting of a T-section, was carried out by Mostafa et al. [11].

Lusis et al. [12] investigated the influence of insertion of short fibers on reinforced concrete's mechanical characteristics using a series of experiments and numerical analysis. They had a significant effect on the tensile strength of the structure. Abid et al. [13] performed a systematic analysis of previous scientific studies based on the strength and durability of concrete beams externally covered by FRP reinforcement. The research study focused on bond behavior, testing techniques, and models used to determine bond performance.

Bennegadi et al. [14] developed a numerical model for optimization of reinforced concrete beams by external (HFRP) plate, and they found that the ultimate load of the reinforced concrete beam was increased when compared to the reference beam, the geometrical and mechanical properties of the HFRP plate must be optimized.

El-Ghandour [15] carried out three-point load checks on seven half-scale reinforced concrete beams, strengthened with longitudinal CFRP sheets and U-wraps. Kara and Ashour [16] developed a numerical system for predicting curvature, deflection, and the moment capacity of reinforced concrete beams strengthened by FRP.

Narmashiri et al. [17] conducted more experimental and numerical research on CFRP-reinforced steel I-beams in terms of failure analysis and structural behavior. They concluded that the geometric and mechanical characteristics control the loadbearing capacity of CFRP plates.

Kermiche and Redjel [18] provided experimental research and an analytical model to simulate the mechanical behavior of concrete and reinforced concrete. Osman et al.,[19]. Performed experimental studies on seven reinforced concrete beams under four-point loads with specific span-to-depth shear ratios. A comparative analysis of 27 reinforced concrete beams with and without CFRP sheets was also carried out.

The findings obtained using ANSYS have been similar to the experimental outcomes of the studies. Considering the previous literature review, it is clear that only few researchers have studied the effect of different CFRP strengthening schemes and locations on bending moment and RC beam failure behaviour.

A total of nineteen FE models were developed to study the flexural behavior of RC beams externally bonded with CFRP sheets. ten specimens were used to validate the accuracy of the numerical model by comparing it with experimental results by Madqour et al.[20] and nine models were developed to investigate the effect of increasing CFRP sheets size.

\section{DESCRIPTION OF THE EXPERIMENTAL PROGRAM}

7 he FE model was created to investigate the flexural behavior of RC beams reinforced with CFRP sheets [20] by Madqour et al. Information on the RC beams is omitted and briefly summarized in the following.

\section{Geometric features of the beams}

A total of ten RC beam specimens strengthened with various schemes were tested by Madqour et al.[20]. The specimens examined included a control beam (B01) reinforced with two steel bars with a diameter of $10 \mathrm{~mm}$. The tested beam has a rectangular cross-section with a nominal width, depth, length of $150 \mathrm{~mm}, 200 \mathrm{~mm}$, and $2000 \mathrm{~mm}$ and spanned over 1800 $\mathrm{mm}$. The compression reinforcing of the specimens tested consisted of two steel bars of $8 \mathrm{~mm}$ diameter Fig. 1 Also, the 6 $\mathrm{mm}$ diameter stirrups spaced at interval $125 \mathrm{~mm}$.

Table 1 provides the characteristics of the examined beams. The deflection of the beams was measured at mid-span using a displacement transducer (LVDT) placed on the beams Fig. 2. 


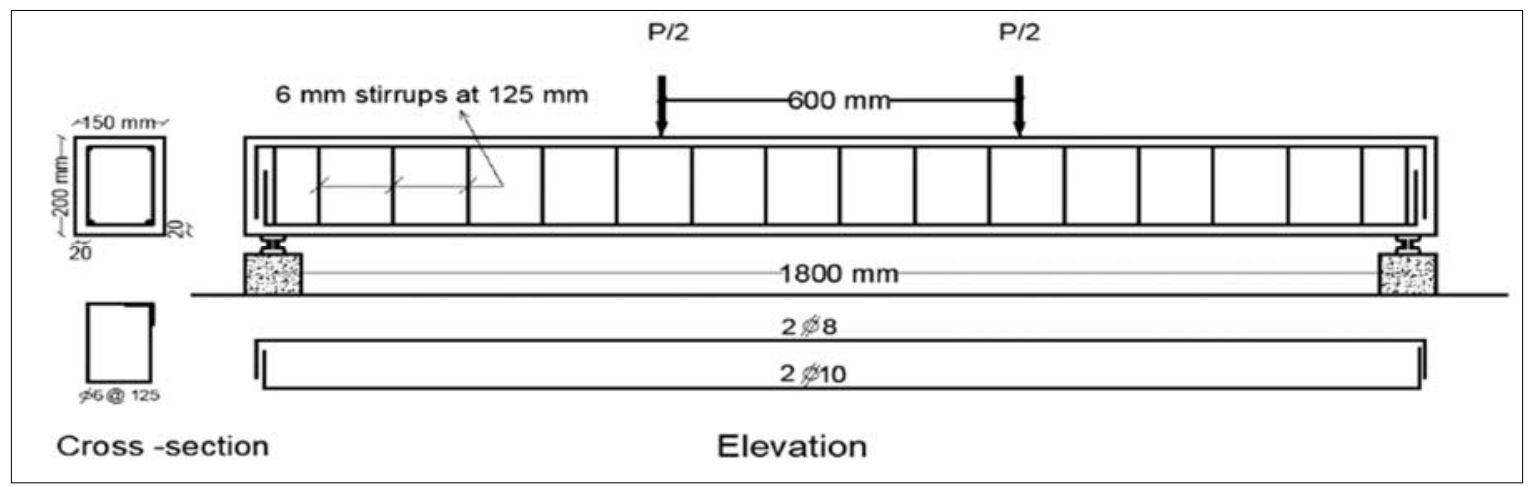

Figure. 1. Details of the tested beams (in $\mathrm{mm}$ ) [18].

\begin{tabular}{cccc} 
Beams designation [20]. & FEM designation & Reinforcement type & FRP width (mm) \\
B00 & S00 & Control beam without strengthening & N/A \\
B02 & S01 & Two layers with lengths 1700, and1400 mm & 100 \\
B04 & S01S & One layer and on both sides with length $1700 \mathrm{~mm}$ & 100 \\
B05 & S01U & One layer and 6 (U-shape) & 100 \\
\hline
\end{tabular}

Table 1: Description of the examined RC beams.

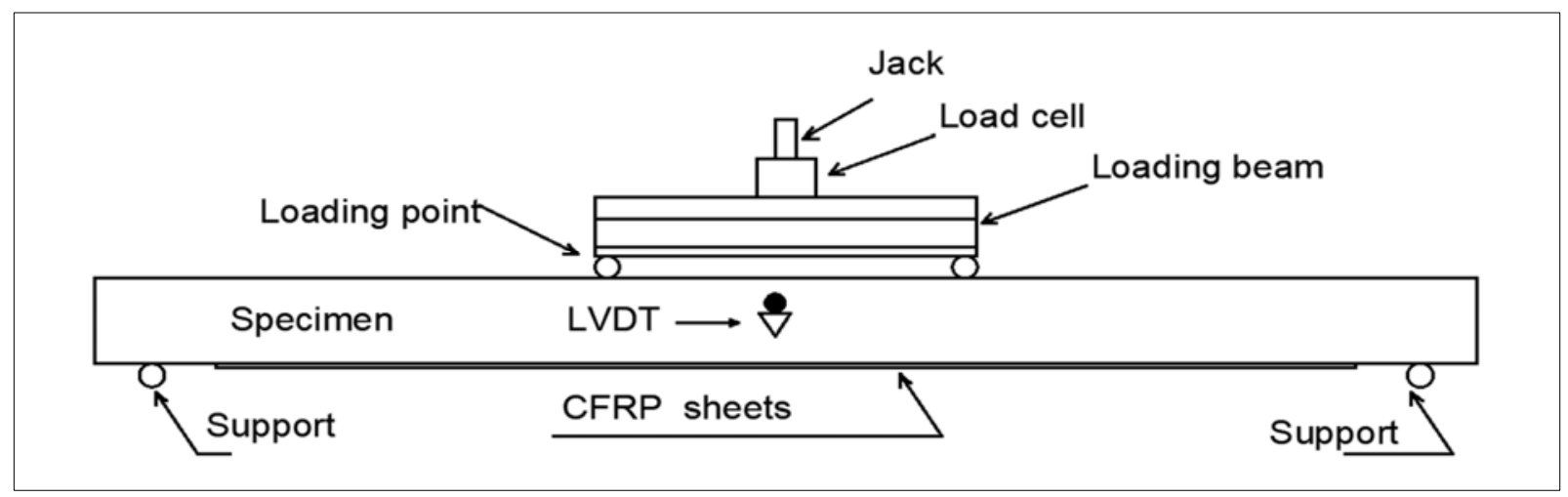

Figure. 2. Test setup.

\section{FINITE ELEMENT MODEL DEVELOPMENT}

everal computer programs packages have been developed to solve finite element problems. ANSYS, NASTRAN, $S$ ADINA, LS-DYNA, MARC, SAP, COSMOS, ABAQUS, and NISA are some of the most commonly used packages. The most recent version of ANSYS 19.1 [21] was selected for use in this research work. It can model non-metal materials and successfully model reinforced concrete as non-homogeneous material with nonlinear response. It also can predict and display the cracking and crushing patterns of the material.

ANSYS 19.0 FE software is used to develop 3D FE specimen models tested by madqour et al. [20]. The geometry, constituent material characteristics, loading, and boundary conditions of the FE models are similar to those of the tested beams previously described in Table 1. 


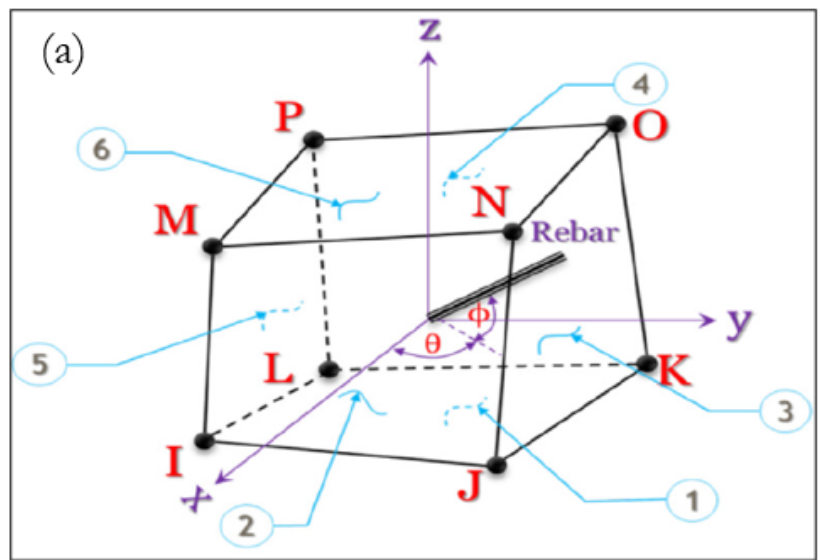

(b)

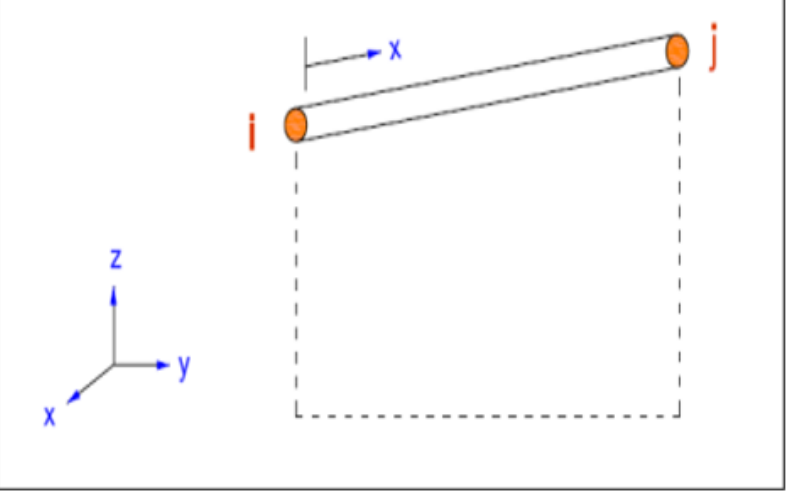

(c)

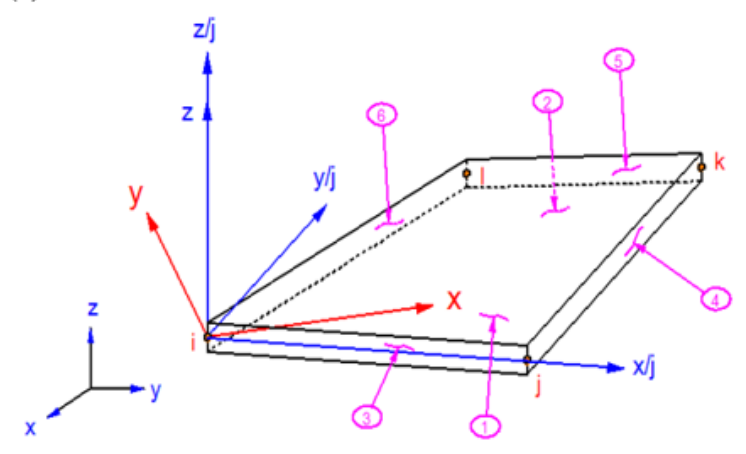

(d)

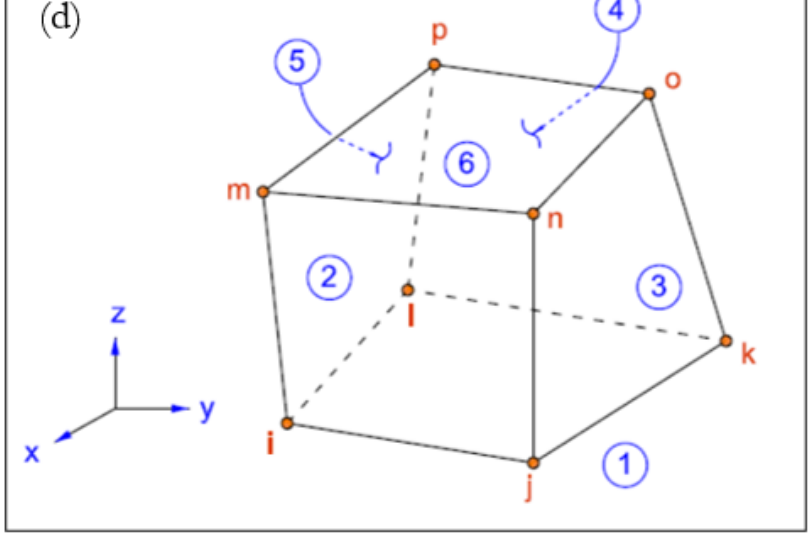

Figure 3: FE models elements: (a) SOLID65 (b) LINK180 (c) SHELL181 (d) SOLID185 layered and SOLID45 [22-27].

\section{Numerical modeling}

The concrete is modeled by using 8-noded SOLID65 Fig 3(a) element, which has three degrees of freedom at each node and can crack in tension and crushing in compression. Fig. 3(a) shows the geometry of the SOLID65 element. Due to the fact that concrete is highly nonlinear in compression, a proper uniaxial stress-strain relationship is used to describe this nonlinearity more precisely, the compressive behavior of concrete is modeled by using the nonlinear stress-strain relation proposed by Popovics, [28] and later modified by Thorenfeldt et al. [29]. Figure (2) shows the curve, which is defined using these Equations. The use of Thorenfeldt et al., [29]'s stress-strain model for concrete in compression was found to be effective for FRP reinforced RC beams by El-Tawil et al., [30].

$$
\begin{aligned}
& \sigma_{c u}=\frac{n f_{c}\left(\frac{\varepsilon_{c}}{\varepsilon_{o}}\right)}{(n-1)+\left(\frac{\varepsilon_{c}}{\varepsilon_{o}}\right)^{n k}} \\
& n=0.80+\frac{f_{c}}{17}
\end{aligned}
$$




$$
\begin{aligned}
& k=\left(0.67+\frac{f_{c}}{62}\right)>1 \quad \text { for } 1<\frac{\varepsilon_{c}}{\varepsilon_{o}} \leq 1 \\
& k=1 \quad \text { for } \frac{\varepsilon_{c}}{\varepsilon_{o}} \leq 1
\end{aligned}
$$

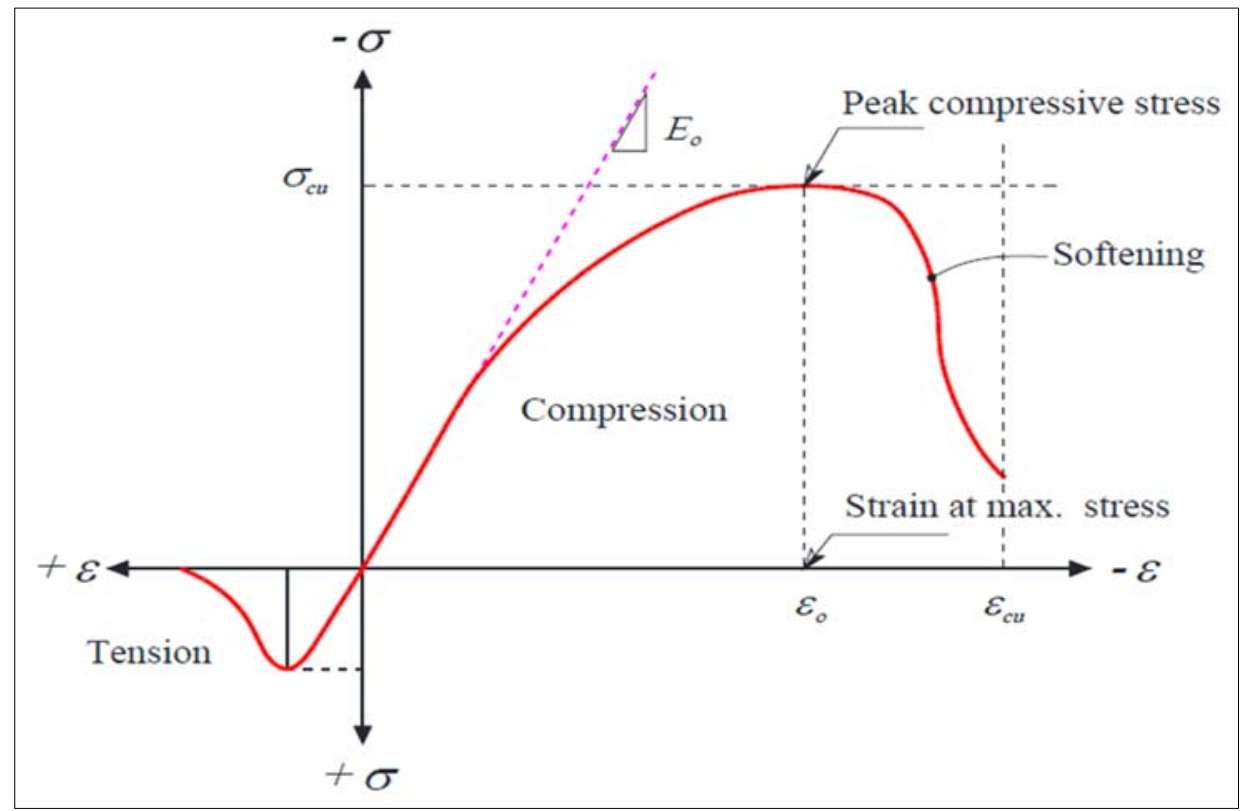

Figure (4): Uniaxial stress-strain curve implemented in the FEM for concrete.Where, $\sigma_{c u}$ is the maximum compressive strength, $\mathcal{E}_{c u}$ is the ultimate strain, and $\mathcal{E}_{0}$ is the strain at maximum stress.

The steel reinforcement modeled with a 3-D spar LINK 180 element having three degrees of freedom at each node (translation in $x, y, z$ directions), as shown in Fig. 3(b). The reinforcement element is assumed to be a bilinear isotropic elastic-perfectly plastic material identical in tension and compression.

SHELL 181 element is used to model the FRP sheet. The thickness of a shell element is relatively small compared to other dimensions of the element. This element is a four-node element with six degrees of freedom at each node: $\mathrm{x}, \mathrm{y}, \mathrm{z}$-direction translations, and x, y, and z-axis rotations Fig.2 (c). To exclude the debonding of FRP sheets, the effective FRP strain should be as recommended by ACI 440.2R-08 [31]. Therefore, such a recommendation is used to modify the debonding FRP strain equation originally proposed by Teng et al. [23]. The effective FRP strain to consider debonding failure in modified form is given by

$$
\varepsilon_{f_{d}}=0.41 \sqrt{\frac{F_{c}}{n E_{f} t_{f}}} \leq 0.9 \varepsilon_{f_{u}}
$$

where, $\varepsilon_{f_{d}}$ is the debonding strain of externally bonded FRP reinforcement, $F_{c}{ }^{\prime}$ is specified compressive strength of concrete, $(\mathrm{MPa}), \mathrm{n}$ is the number of layers, $E_{f}$ is the tensile modulus of elasticity of FRP, $(\mathrm{MPa}), t_{f}$ is the nominal thickness of one ply of FRP reinforcement, (mm), and $\varepsilon_{f_{u}}$ is the design rupture strain of FRP reinforcement. 
SOLID 185 element is used to model the loading supports. Eight nodes represent this element Fig.2(d), each having three degrees of freedom in the nodal directions $\mathrm{x}, \mathrm{y}$, and z. Plasticity, stress stiffening, creeping, large deflection, and high strain power are all capabilities of the element.

The adhesive is modeled using the element SOLID45 Fig. 2(d). It is an eight-node three-dimensional structure with three degrees of freedom at each node, i.e., translations in directions nodal $\mathrm{x}, \mathrm{y}$, and $\mathrm{z}$. The element has the capacity for plasticity, creeping, swelling, stress stiffening, large deflection, and significant strain. Hawileh et al. [24] used the SOLID45 element to model adhesive and obtained satisfactory results in the study of RC beams reinforced by FRP. This system consists of two nodes, one set of nodes with the concrete element used in this analysis and another with FRP elements.

The material properties of the concrete, steel reinforcement, CFRP, steel plate, and epoxy used in the developed FE models are summarized in Table 2.

\begin{tabular}{cccc}
\hline Material & FE type & Properties & Values \\
& & Compressive strength (MPa) & 32 \\
& & Modulus of elasticity (GPa) & 30.6 \\
& & Poisson's ratio(v) & 0.25 \\
Concrete & \multirow{2}{*}{ SOLID 65 } & Modulus of elasticity (GPa) & 200 \\
& & Open shear Transfer & 0.50 \\
& & Closed shear coefficient & 0.80 \\
& & Uniaxial cracking (ft) & 32 \\
& & Uniaxial crushing (fc) & 3.4 \\
\hline \multirow{2}{*}{ Reinforcement } & \multirow{2}{*}{ LINK 180el } & Yield strength (MPa) (Longitudinal) & 525 \\
& & Yield strength (MPa) (stirrups) & 400 \\
& & Poisson's ratio(v) & 0.20 \\
& & Elastic modulus (MPa) & 200000 \\
\hline \multirow{2}{*}{ CFRP } & \multirow{2}{*}{ SHELL 181 } & Modulus of elasticity (GPa) & 230 \\
& & Design thickness (mm/ply) & 0.129 \\
& \multirow{2}{*}{ SOLID45 } & Tensile strength (MPa) & 4000 \\
\hline \multirow{2}{*}{ Epoxy } & \multirow{2}{*}{ Steel plate } & Modulus of elasticity (GPa) & 4.50 \\
& \multirow{2}{*}{ SOLID185 } & Tensile strength (MPa) & 30 \\
\hline \multirow{2}{*}{} & & Elastic modulus (MPa) & 200000 \\
& & Poisson's ratio & 0.3 \\
\hline
\end{tabular}

Table 2: Material properties concrete, reinforcement steel, CFRP, epoxy, and steel plate.

\section{FE MODEL VALIDATION}

$\mathrm{T}$ he flexural behavior of RC beams externally strengthening with CFRP sheets is studied using a total of nineteen FE models. The accuracy of the numerical model is validated by comparing experimental results with the ten beams reported in Table 1, and the remaining models are developed to study the effect of CFRP width and sheet size on the flexural behavior of the beams. Fig. 4 shows the developed FE models for a RC beam, externally strengthening with CFRP sheets.

The four beams detailed in the previous section are modeled and to evaluate the accuracy of the numerical models. the predicted and obtained experimental data are compared for all beams.

For four beams, in Fig. 5 are plotted the experimental and predicted results in terms of load versus mid-span deflection. Table 3 compares the FE results and experimental measured data in terms of attained load ( $\mathrm{Pu}$ ) along with its corresponding mid-span deflection $(\delta \mathrm{u})$ value. 

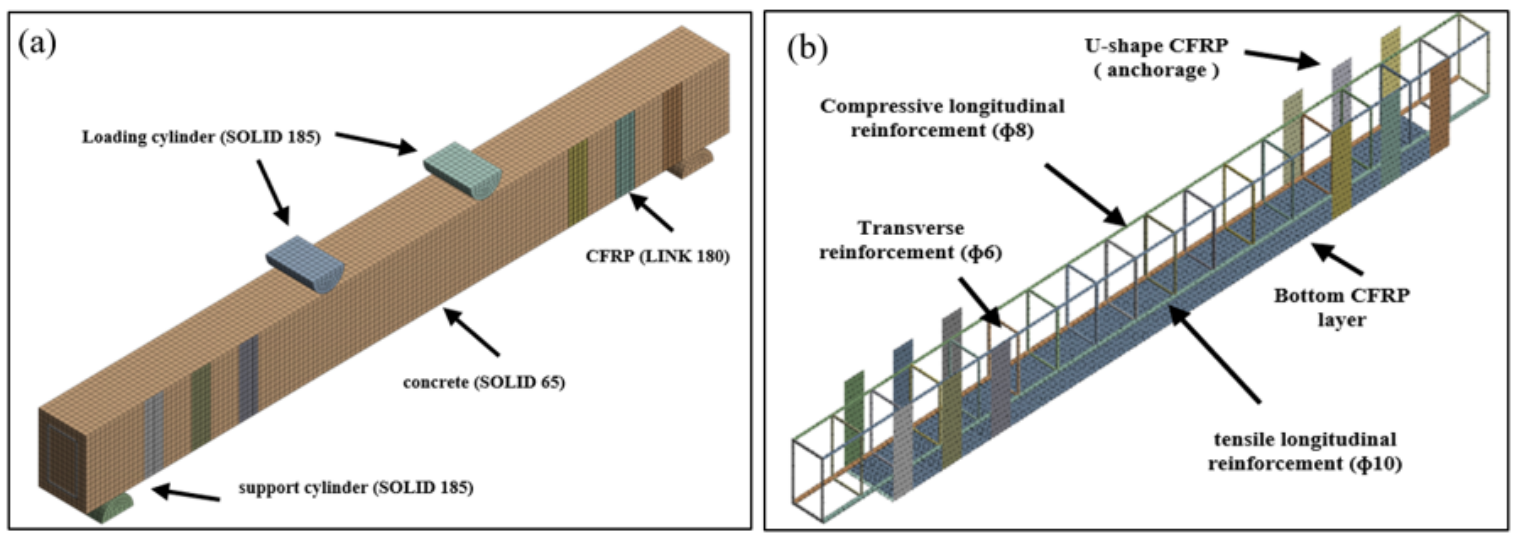

Figure 5: Finite element model of a RC beam: (a) numerical model; (b) modeling of longitudinal reinforcement without stirrups and modeling of longitudinal reinforcement with stirrups.
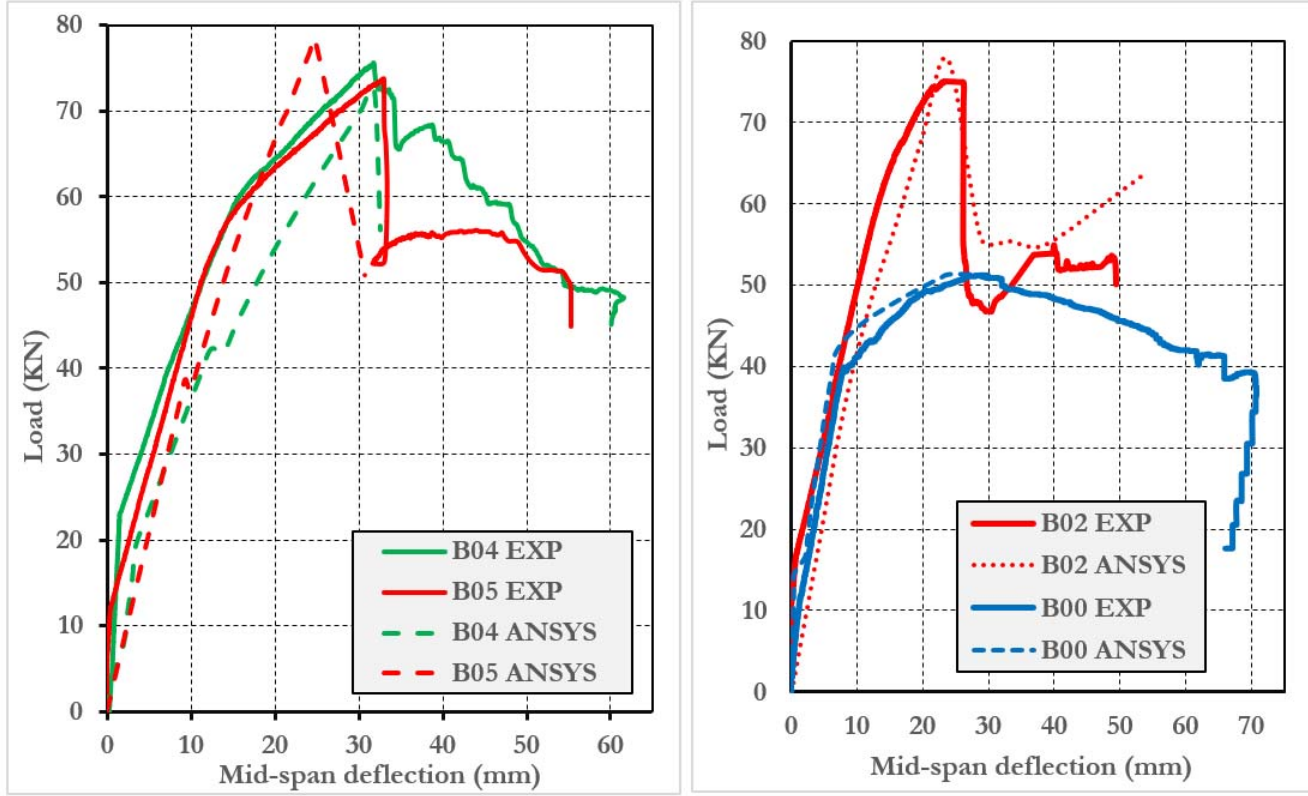

Figure 6: Comparison between experimental and numerical load-deflection curve for B00, B02, B04, and B05 beams.

\begin{tabular}{ccccc}
\hline \multirow{2}{*}{ Beam No. } & \multicolumn{2}{c}{ Ansys $(100 \mathrm{~mm}$ width) } & \multicolumn{2}{c}{ Experimental } \\
& Load $(\mathrm{kN})$ & Deflection $(\mathrm{mm})$ & Load $(\mathrm{kN})$ & Deflection $(\mathrm{mm})$ \\
B00 & 51.39 & 30 & 51.20 & 32.01 \\
B02 & 72.43 & 31.76 & 75.66 & 31.74 \\
B04 & 77.67 & 23.82 & 75.1 & 26.13 \\
B05 & 80.08 & 24.87 & --- & --- \\
\hline
\end{tabular}

Table 3: Comparison between experimental and numerical results for B00, B02, B04, and B05 beams.

\section{PARAMETRIC STUDY}

$\mathrm{I}$

$\mathrm{n}$ this section, parametric research is carried out by developing and analyzing nine additional FE models to investigate the influence of CFRP laminate size (width) and different schemes of FRP laminates on the flexural response and strength of RC beams externally strengthened with sheets as in Fig. 7. 


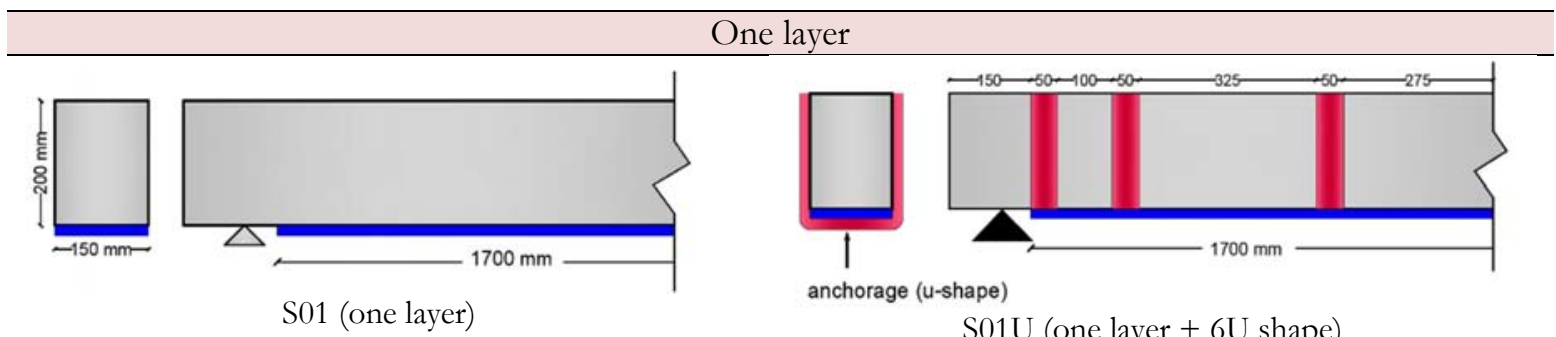

$\mathrm{S} 01 \mathrm{U}$ (one layer $+6 \mathrm{U}$ shape)

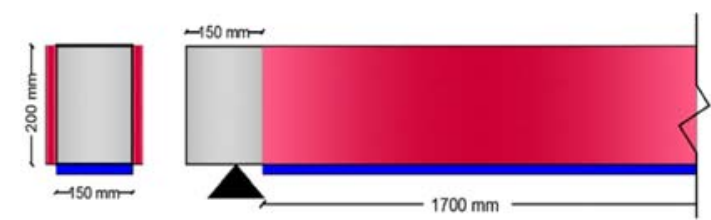

S01S (one layer + on sides)

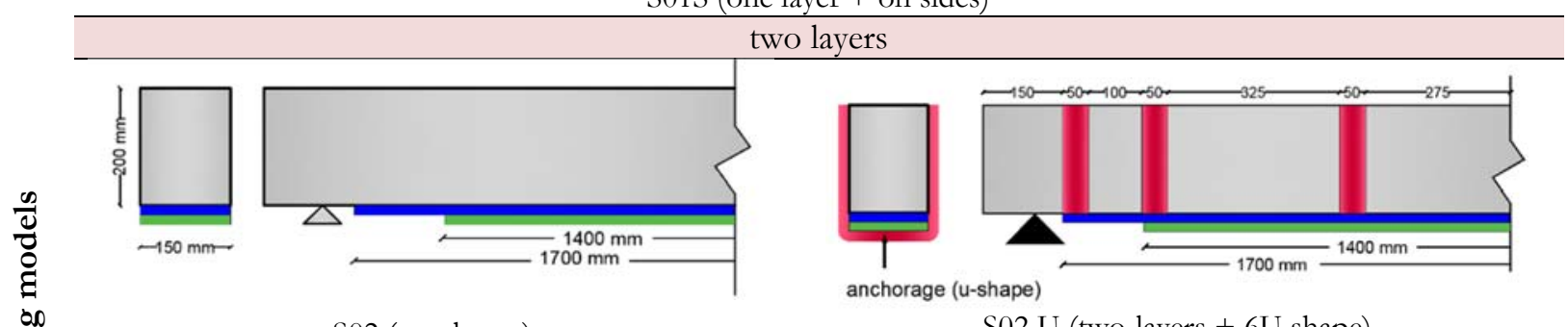

S02 (two layers)

S02 U (two-layers + 6U shape)

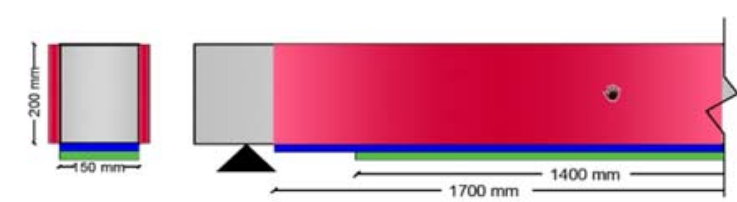

S02 S (two layers + on sides)

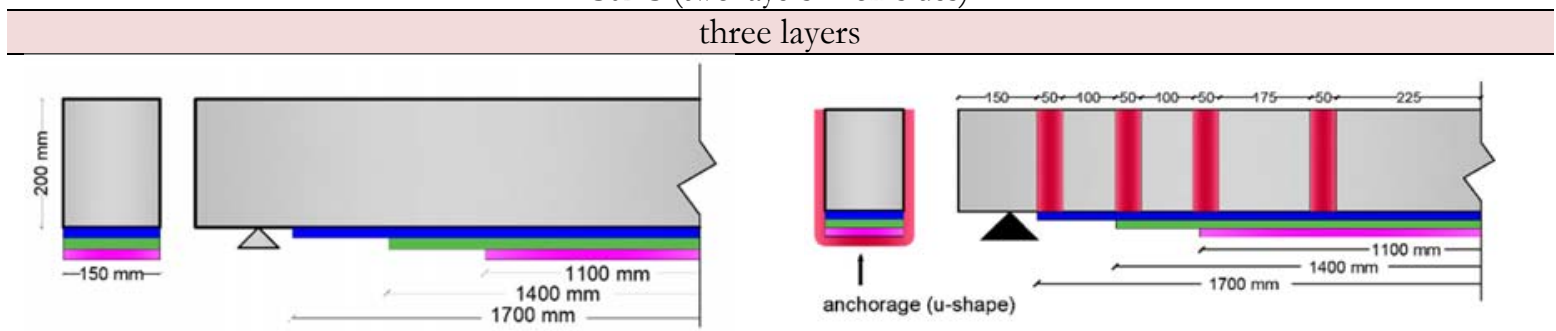

S03 (three layers)

S03U (three-layers + 8U shape)

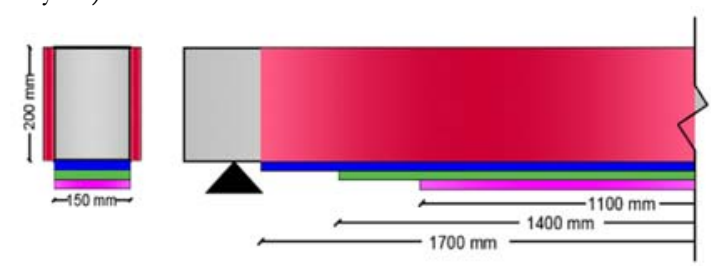

S03 S (three layers + on sides)

Figure 7: Strengthening configurations of specimens

To investigate the behavior of the beam when the size (width) of CFRP sheets is changed, nine FE models were developed. One of the beams was modeled as an un-strengthened control, while the other eight were strengthened using CFRP sheets 
of varying width of $150 \mathrm{~mm}$. Table 3 lists the designations for each studied model. Figure 6 shows the predicted load versus mid-span displacement response curves. Table 3 further summarizes the predicted ultimate achieved load $(\mathrm{Pu})$ and its corresponding mid-span deflection (u).

\section{Effect of CFRP sheet size for the case one layer}

As expected, the beams with a width of $150 \mathrm{~mm}$ bonded FRP sheets obtained a larger load-carrying capacity (flexural strength) than the beams with a width of $100 \mathrm{~mm}$, as shown in Fig. 8 and Table 4. The load-carrying capacity (Pu) of beam S01, which has a $150 \mathrm{~mm}$ wide CFRP sheet, is $8 \%$ greater than the control specimen. Fig. 8 further shows that the increase in Pu for beams S01U with $150 \mathrm{~mm}$ wide CFRP sheets and S01S with $150 \mathrm{~mm}$ wide CFRP sheets was $7.98 \%$ and $12.95 \%$, respectively. As a result, the increase in the load-carrying capacity of a beam is inversely proportional to the increase in CFRP laminates' size (width).

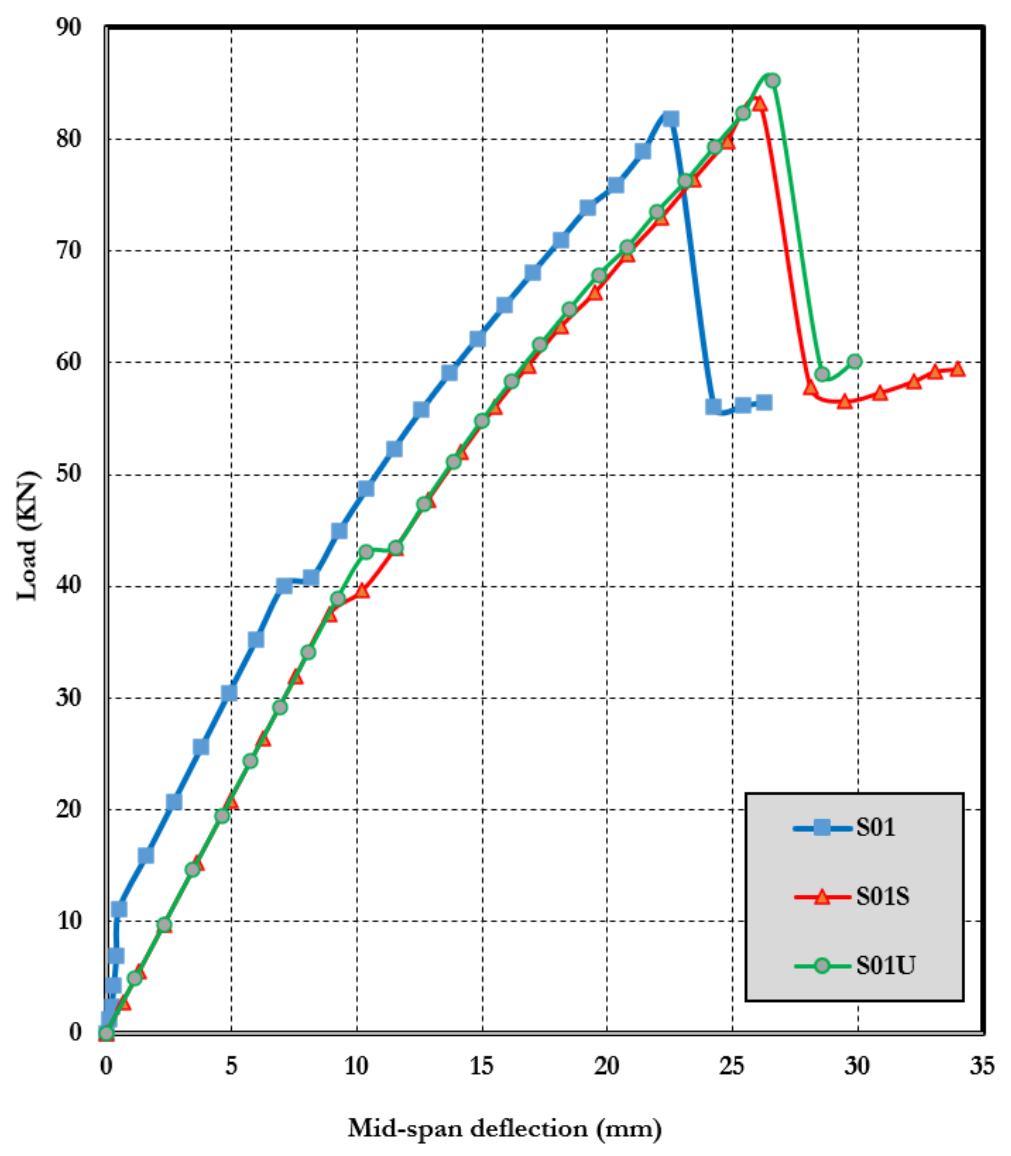

Figure 8: Numerical load-deflection curve for S01, S01S, and S01U beams.

\section{Effect of CFRP sheet size for case of two-layers}

The load versus mid-span deflection curves for the two layers are provided in Fig. 9. The load capacity (Pu) of beam S02, which has a $150 \mathrm{~mm}$ wide CFRP sheet, is $12.8 \%$ greater than that of the control specimen. Table 4 further shows that the increase in Pu for beams S02U with $150 \mathrm{~mm}$ wide CFRP sheets and S02S with $150 \mathrm{~mm}$ wide CFRP sheets was $9.58 \%$ and $10.47 \%$, respectively, as a result, the increase in the load capacity of a beam is inversely proportional to the increase in the width of CFRP sheets. 


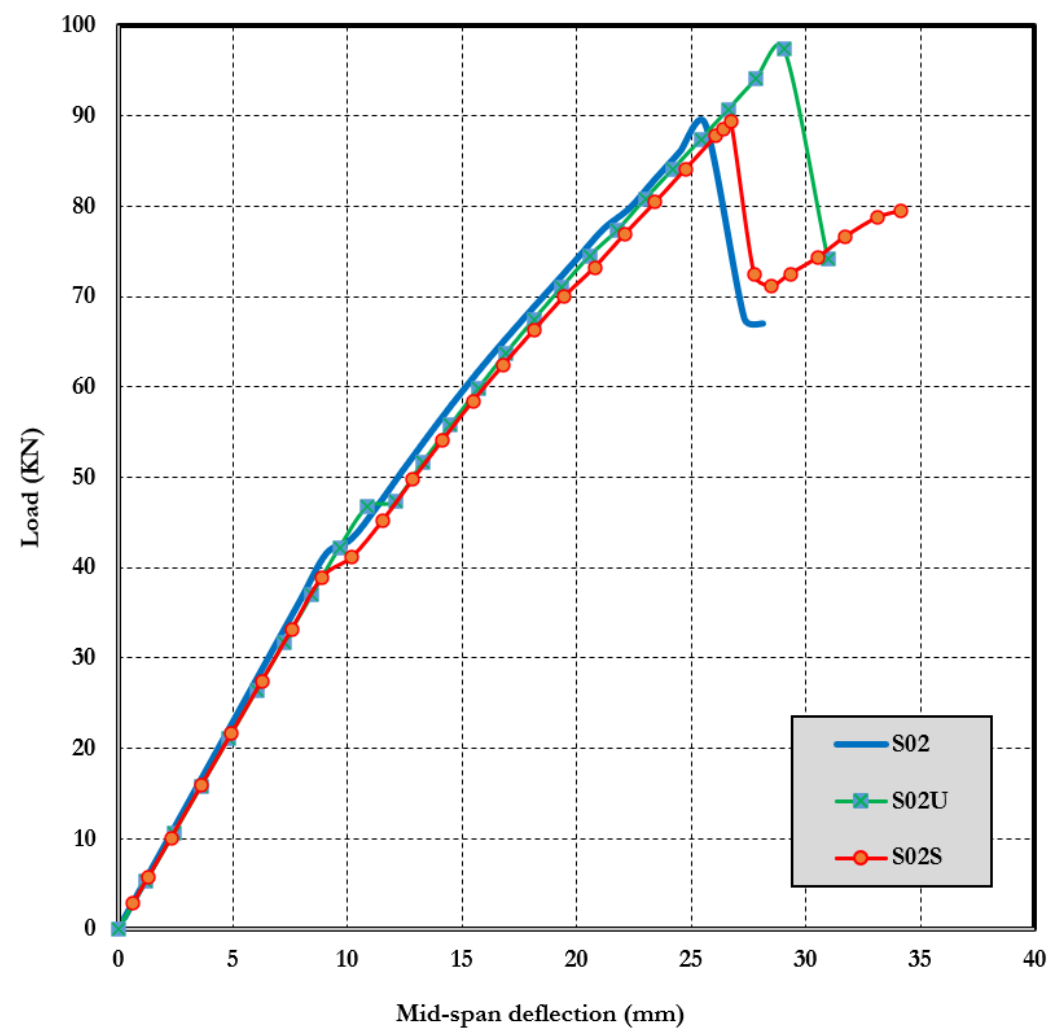

Figure 9: Numerical load-deflection curve for S02, S02S, and S02U beams.

\section{Effect of CFRP sheet size for in case of three-layers}

The predicted load versus mid-span deflection curves for the three layers are provided in Fig. 10. The ultimate load of beam S03 with a $150 \mathrm{~mm}$ wide CFRP sheet is $22.50 \%$ greater than that of the control specimen. Table 4 shows that the increase in Pu for beams S03U with $150 \mathrm{~mm}$ wide CFRP sheets and S03S with $150 \mathrm{~mm}$ wide CFRP sheets was $14.10 \%$ and 14.32 $\%$, respectively.

\begin{tabular}{ccccccc}
\hline Beam No. & \multicolumn{2}{c}{ Ansys $(100 \mathrm{~mm}$ width) } & \multicolumn{2}{c}{ Ansys $(150 \mathrm{~mm}$ width $)$} & \multicolumn{2}{c}{ Experimental } \\
& $\begin{array}{c}\text { Load } \\
(\mathrm{kN})\end{array}$ & $\begin{array}{c}\text { Deflection } \\
(\mathrm{mm})\end{array}$ & $\begin{array}{c}\text { Load } \\
(\mathrm{kN})\end{array}$ & $\begin{array}{c}\text { Deflection } \\
(\mathrm{mm})\end{array}$ & $\begin{array}{c}\text { Load } \\
(\mathrm{kN})\end{array}$ & $\begin{array}{c}\text { Deflection } \\
(\mathrm{mm})\end{array}$ \\
CB & 51.39 & 30 & 51.39 & 30 & 51.20 & 32.01 \\
S01 & 75.21 & 23.92 & 81.78 & 28.25 & 69.44 & 27.72 \\
S01S & 72.43 & 31.76 & 83.20 & 34.01 & 75.66 & 31.74 \\
S01U & 78.43 & 24.79 & 85.23 & 29.85 & 73.76 & 32.96 \\
S02 & 77.67 & 23.82 & 89.08 & 28.14 & 75.1 & 26.13 \\
S02S & 80.08 & 24.87 & 89.45 & 26.74 & --- & --- \\
S02U & 88.03 & 24.53 & 97.36 & 30.96 & 87.85 & 36.96 \\
S03 & 76.39 & 23.69 & 98.59 & 28.50 & 79.39 & 23.33 \\
S03S & 86.88 & 26.09 & 101.41 & 27.39 & --- & --- \\
S03U & 86.43 & 26.48 & 100.62 & 29.93 & 88.78 & 30.97 \\
\hline
\end{tabular}

Table 4: Comparison between analytical and experimental results. 


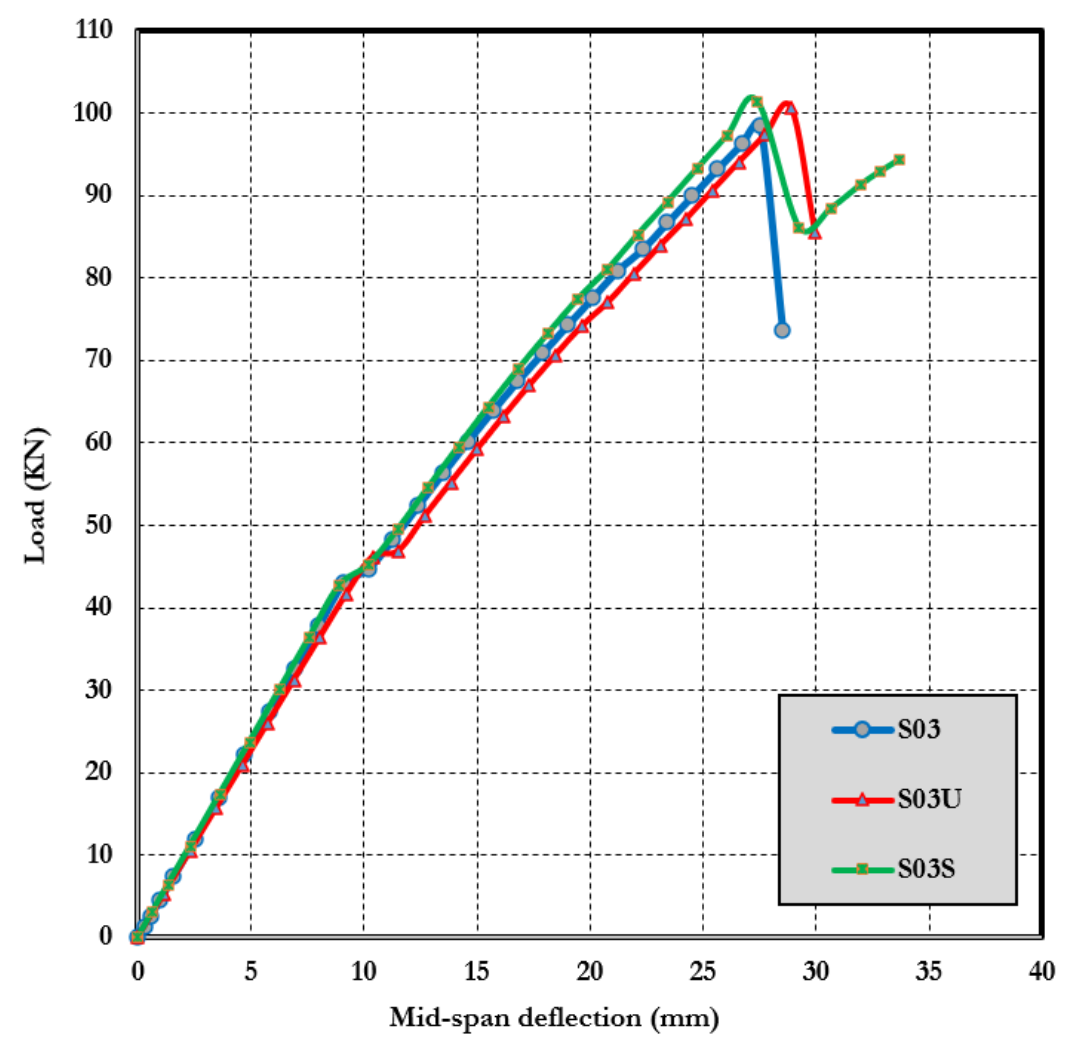

Figure 10: Numerical load-deflection curve for S03, S03S, and S03U beams.

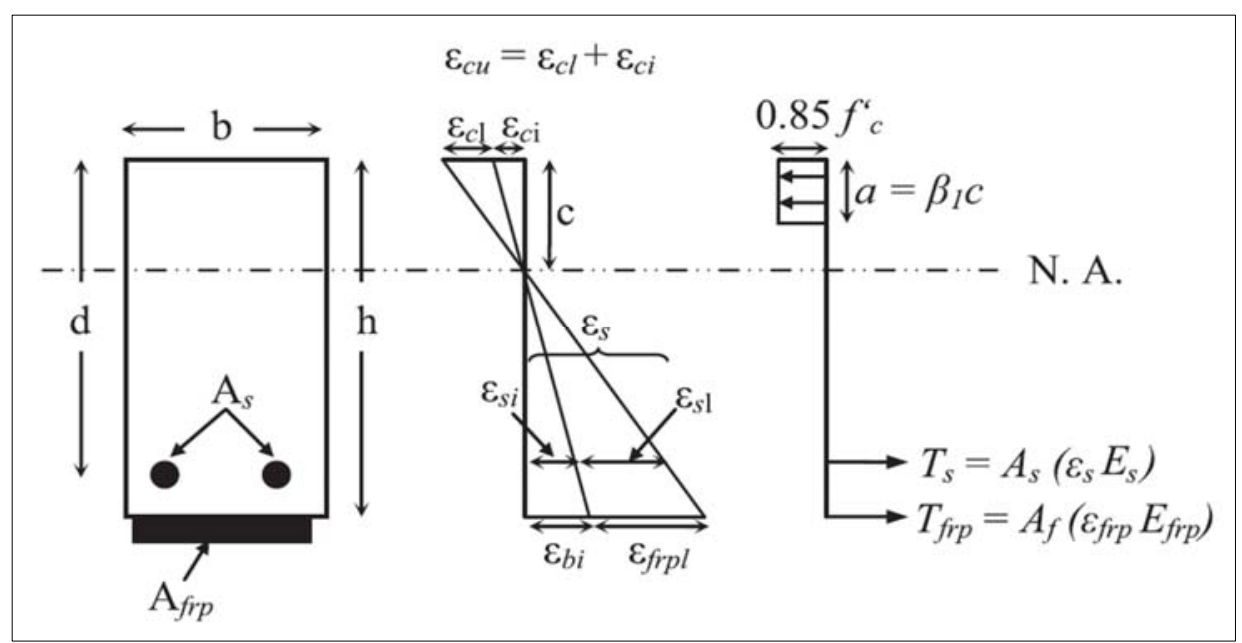

Figure 11: Strain distribution and force equilibrium conditions for externally strengthened FRP beams.

\section{THEORETICAL PREDICTION OF BEAM CAPACITIES}

everal research, including Wenwei et al. [32] and Chellapandian et al. [33], compared the experimental and theoretical 
According to ACI, the bending moment of externally bonded FRP beams is calculated using strain compatibility, internal force equilibrium, and governing modes of failure [31]. The strain distribution and force equilibrium conditions for externally reinforced FRP beams are depicted in Figure (11).

According to GangaRao and Vijay[34], ACI [31], the modes of failure in externally reinforced FRP beams are

(1) tension-controlled failure with FRP rupture $\left(\varepsilon \mathrm{s} \geq 0.005>\varepsilon \mathrm{sy}, \varepsilon_{f p}=\varepsilon_{f p p u}\right)$;

(2) tension-controlled failure without FRP rupture $\left(\varepsilon \mathrm{s} \geq 0.005>\varepsilon \mathrm{sy}, \varepsilon_{f p}<\varepsilon_{f p u}, \varepsilon \mathrm{cu}=0.003\right)$;

(3) tension and compression-controlled failure $\left(\varepsilon\right.$ sy $\leq 0.005<\varepsilon$ sy, $\varepsilon_{f p p}<\varepsilon_{f p h u}, \varepsilon$ cu $\left.=0.003\right)$;

(4) compression-controlled failure ( $\left.\varepsilon \mathrm{s} \leq \varepsilon \mathrm{sy}, \varepsilon_{f p p}<\varepsilon_{f p h u}\right)$; and

(5) balanced failure $\left(\varepsilon \mathrm{s}=\varepsilon \mathrm{u}=0.003, \varepsilon_{f p p}=\varepsilon_{f p u}, \varepsilon \mathrm{s} \geq \varepsilon \mathrm{sy}\right)$.

\section{Strain and stress in FRP:}

FRP reinforcement is assumed to behave linearly elastic manner until failure. Furthermore, the FRP stress is proportional to strain. The maximum strain obtained in the FRP reinforcement is determined by either the strain level developed in the FRP at the point where the concrete crushes, the FRP ruptures, or the FRP debonds from the substrate. The effective strain level in FRP reinforcement at the ultimate can be calculated using the following expression:

$$
\begin{aligned}
\varepsilon f_{e} & =\varepsilon_{c u}\left(\frac{h-c}{c}\right)-\varepsilon b_{i} \leq k_{m} \varepsilon f_{u} \\
\varepsilon b_{i} & =\frac{M_{D L}(b-k d)}{I_{C r} E C} \\
k & =\sqrt{\left[\rho_{s} \frac{E_{s}}{E c}+\rho_{f} \frac{E f}{E c}\right]^{2}+2\left[\rho_{s} \frac{E_{s}}{E c}+\rho_{f} \frac{E f}{E c}\left(\frac{b}{d}\right)\right]}-\left[\rho_{s} \frac{E_{s}}{E_{c}}+\rho_{f} \frac{E f}{E c}\right]
\end{aligned}
$$

The effective stress level in the FRP reinforcement can be calculated as follows:

$$
f_{f e}=E_{f} \varepsilon f_{e}
$$

Concrete delamination or FRP debonding can occur if the substrate cannot sustain the force in FRP. To prevent the debonding of FRP reinforcement, a limitation should be provided on the strain level developed in the FRP reinforcement. The bond dependent coefficient $\mathrm{km}$ is given as follows:

$$
k_{m}=\frac{1}{60 \varepsilon f u}\left(1-\frac{n E_{f} t_{f}}{360,000}\right) \leq 0.90 \text { for } n E_{f} t_{f} \leq 180,000
$$

OR

$$
k_{m}=\frac{1}{60 \varepsilon f u}\left(1-\frac{360,000}{n E_{f} t_{f}}\right) \leq 0.90 \text { for } n E_{f} t_{f}>180,000
$$

The flexural strength of beams with FRP external reinforcement can be computed using Equation (11). The additional strength reduction factor $\left(\psi_{f}=0.85\right)$ is applied to the flexural strength contribution of the FRP reinforcement. 


$$
M n=\left[A_{s} f y\left(d-\frac{a}{2}\right)+\psi_{f} A_{f}\left(E_{f} \varepsilon_{f}\right)\left(b-\frac{a}{2}\right)\right]
$$

The theoretical bending moment values are calculated by incorporating the additional strength reduction factor, $\psi_{f}$. Table 5 shows the final results of the theoretical method.

\begin{tabular}{ccc}
\hline Beam No. & $\begin{array}{c}\text { Theoretical Load (kN) } \\
(100 \mathrm{~mm} \text { CFRP width) }\end{array}$ & $\begin{array}{c}\text { Theoretical Load }(\mathrm{kN}) \\
(150 \mathrm{~mm} \text { CFRP width })\end{array}$ \\
CB & 47.01 & 47.01 \\
S01 & 66.66 & 72.79 \\
S02 & 77.85 & 86.09 \\
S03 & 86.08 & 95.58 \\
S01S & 79.32 & 86.52 \\
S02S & 85.73 & 94.43 \\
S03S & 90.23 & 99.82 \\
\hline
\end{tabular}

Table 5: Results of the theoretical method.

\section{CONCLUSION}

he main aim of the research is to investigate the influence of increasing CFRP sheet size and width, the models have been validated by comparing the behaviour and response of nine beam specimens. At all levels of loading until failure, the numerical and experimental data demonstrated a high correlation, and it can conclude that.

- The FE models accurately predicted the flexural behaviour of the tested reinforced concrete beam specimens with and without CFRP sheet reinforcement.

- Increasing the number of layers of FRP sheets increases the ultimate strength of RC beams up to $100 \%$ compared to the control beam. However, the mid-span deflections are less than those of the control specimen.

- By increasing the width of CFRP sheets increases beam load capacity.

\section{REFERENCES}

[1] Kang, T. H. K., Howell, J., Kim, S. and Lee, D. J. (2012). A state-of-the-art review on debonding failures of FRP laminates externally adhered to concrete. International Journal of Concrete Structures and Materials, 6(2), pp. 123-134.

[2] Bennati, S., Dardano, N. and Valvo, P. S. (2012). A mechanical model for FRP-strengthened beams in bending. Frattura ed Integrità Strutturale, 6(22), pp. 39-55.

[3] Cunha, R., Oliveira, K., Brito, A., Vieira, C. and Amorim, D. (2021). Evaluation of the behaviour of reinforced concrete beams repaired with glass fibre reinforced polymer (GFRP) using a damage variable. Frattura ed Integrità Strutturale, 15(57), pp. 82-92.

[4] Benaoum, F., Khelil, F. and Benhamena, A. (2020). Numerical analysis of reinforced concrete beams pre cracked reinforced by composite materials. Frattura ed Integrità Strutturale, 14(54), pp. 282-296.

[5] Ueda, T., Sato, Y. and Asano, Y. (1999). Experimental study on bond strength of continuous carbon fiber sheet. Special Publication, 188, pp. 407-416.

[6] Carloni, C., Ali-Ahmad, M. and Subramaniam, K. (2005, August). Scaling effect in FRP/concrete interface debonding. In Proceedings of the 7 th International Conference on Mesomechanics, pp. 1-4.

[7] RILEM, T. Q. F. S. (2004). Quasibrittle fracture scaling and size effect-Final report. Mater. Struct, 37272, pp. 547586. 
[8] Kamel, A. S., Elwi, A. A. and Cheng, R. J. (2004). Experimental investigation on FRP sheets bonded to concrete. Emirates Journal for Engineering Research, 9(2), pp. 71-76.

[9] Travassos, N. A. C., Gomes, A. M. and Universidade Técnica de Lisboa. (2005). Caracterização do comportamento da ligação CFRP-betão.

[10] Hashemi, S. and Al-Mahaidi, R. (2010). Investigation of bond strength and flexural behaviour of FRP-strengthened reinforced concrete beams using cement-based adhesives. Australian Journal of Structural Engineering, 11(2), pp. 129139.

[11] Mostafa, A. A. and Razaqpur, A. G. (2017). Finite element model for predicting post delamination behaviour in FRPretrofitted beams in flexure. Construction and Building Materials, 131, pp. 195-204.

[12] Lusis, V., Krasnikovs, A., Kononova, O., Lapsa, V. A., Stonys, R., Macanovskis, A. and Lukasenoks, A. (2017). Effect of short fibers orientation on mechanical properties of composite material-fiber reinforced concrete. Journal of Civil Engineering and Management, 23(8), pp. 1091-1099.

[13] Abid, S. R. and Al-lami, K. (2018). Critical review of strength and durability of concrete beams externally bonded with FRP. Cogent engineering, 5(1), 1525015.

[14] Bennegadi, M. L., Sereir, Z. and Amziane, S. (2013). 3D nonlinear finite element model for the volume optimization of a RC beam externally reinforced with a HFRP plate. Construction and Building Materials, 38, pp. 1152-1160.

[15] El-Ghandour, A. A. (2011). Experimental and analytical investigation of CFRP flexural and shear strengthening efficiencies of RC beams. Construction and Building Materials, 25(3), pp. 1419-1429.

[16] Kara, I. F. and Ashour, A. F. (2012). Flexural performance of FRP reinforced concrete beams. Composite structures, 94(5), pp. 1616-1625.

[17] Narmashiri, K., Sulong, N. R. and Jumaat, M. Z. (2012). Failure analysis and structural behaviour of CFRP strengthened steel I-beams. Construction and building materials, 30, pp. 1-9.

[18] Kermiche, S. and Redjel, B. (2012). Analyse expérimentale et analytique du comportement en flexion des poutres en béton armé préfissurées renforcées par un matériau composite en toile de fibres de carbone (TFC). Synthèse: Revue des Sciences et de la Technologie, 25, pp. 41-58.

[19] Osman, B. H., Wu, E., Ji, B. and Abdulhameed, S. S. (2018). Effect of reinforcement ratios on shear behavior of concrete beams strengthened with CFRP sheets. HBRC journal, 14(1), pp. 29-36.

[20] Madqour, M. and Hassan, H. (2021). Experimental and analytical investigations of reinforced concrete beams strengthened by different CFRP sheet schemes. Frattura ed Integrità Strutturale, 15(56), pp. 123-136.

[21] ANSYS. A Finite element computer software and user manual for nonlinear structural analysis. Canonsburg, PA.: ANSYS 2007; Inc; (2007).

[22] Aiello, M. A., Ascione, L., Baratta, A., Bastianini, F., Battista, U., Benedetti, A. and Zampa, A. (2014). Guide for the design and construction of externally bonded FRP systems for strengthening existing structures.

[23] Teng, J. G., Smith, S. T., Yao, J. and Chen, J. F. (2003). Intermediate crack-induced debonding in RC beams and slabs. Construction and building materials, 17(6-7), pp. 447-462.

[24] Hawileh, R. A., Naser, M. Z. and Abdalla, J. A. (2013). Finite element simulation of reinforced concrete beams externally strengthened with short-length CFRP plates. Composites Part B: Engineering, 45(1), pp. 1722-1730.

[25] Version, A. R. (2009). 12.1. 0, A Finite Element Computer Software and User Manual for Nonlinear Structural Analysis, ANSYS Inc. Canonsburg, PA.

[26] F. Bouziadi, Boulekbache, B., Haddi, A., Djelal, C., Hamrat, M. J. C. and B. Materials, (2018). Numerical analysis of shrinkage of steel fiber reinforced high-strength concrete subjected to thermal loading, Construction and Building Materials, 181, pp. 381-393.

[27] Bouziadi, F., Boulekbache, B., Haddi, A., Hamrat, M. and Djelal, C. (2020). Finite element modeling of creep behavior of FRP-externally strengthened reinforced concrete beams. Engineering Structures, 204, 109908.

[28] Popovics, S. (1970, March). A review of stress-strain relationships for concrete. In Journal Proceedings, 67(3), pp. 243248).

[29] Thorenfeldt, E. (1987). Mechanical properties of high-strength concrete and applications in design. In Symposium Proceedings, Utilization of High-Strength Concrete, Norway.

[30] El-Tawil, S., Ogunc, C., Okeil, A. and Shahawy, M. (2001). Static and fatigue analyses of RC beams strengthened with CFRP laminates. Journal of composites for construction, 5(4), pp. 258-267. 
[31] ACI Committee, (2005), Building Code Requirements for Structural Concrete (ACI 318-05) and Commentary (ACI 318R-05), American Concrete Institute.

[32] Wenwei, W. and Guo, L. (2006). Experimental study and analysis of RC beams strengthened with CFRP laminates under sustaining load. International Journal of Solids and Structures, 43(6), pp. 1372-1387.

[33] Chellapandian, M., Prakash, S. S. and Sharma, A. (2019). Experimental and finite element studies on the flexural behavior of reinforced concrete elements strengthened with hybrid FRP technique. Composite Structures, 208, pp. 466478.

[34] GangaRao, H. V. and Vijay, P. V. (1998). Bending behavior of concrete beams wrapped with carbon fabric. Journal of structural engineering, 124(1), pp. 3-10.

\section{NOMENCLATURE}

a Depth of equivalent rectangular stress block

$\mathrm{A}_{\text {frp }} \quad=\mathrm{ntf} w f$, area of FRP external reinforcement

$\mathrm{A}_{\mathrm{s}} \quad$ Area of non-prestressed steel reinforcement

b Width of rectangular cross-section

c Distance from extreme compression fiber to the neutral axis

d The effective depth of the beam

$\mathrm{E}_{\mathrm{c}} \quad$ Modulus of elasticity of concrete

$\mathrm{E}_{\mathrm{frp}}$ or $\mathrm{E}_{\mathrm{f}} \quad$ Tensile modulus of elasticity of FRP

$E_{s}$ and $E_{c} \quad$ Modulus of elasticity of steel and concrete

$f_{c} \quad$ The compressive strength of the concrete

$\mathrm{f}_{\mathrm{fe}} \quad$ Effective stress in FRP; stress level attained at section failure

$f_{y} \quad$ Yield strength of non-prestressed steel reinforcement

$f_{c} \quad$ Compressive strength of concrete

$\mathrm{h} \quad$ Overall depth of the beam

$\mathrm{I}_{\mathrm{cr}} \quad$ Moment of inertia of cracked section transformed to concrete

$\mathrm{k}_{\mathrm{m}} \quad$ Bond-reduction coefficient for flexure

$\mathrm{k}$ The ratio of the depth of the neutral axis to reinforcement depth measured on the same side of the neutral axis

$\mathrm{M}_{\mathrm{DL}} \quad$ Bending moment due to dead-load

$\mathrm{M}_{\mathrm{n}} \quad$ Nominal bending moment

$\mathrm{n} \quad$ Number of FRP layers

$t_{f} \quad$ Nominal thickness of one ply of FRP reinforcement

$\mathrm{T}_{\text {frp }} \quad$ Tensile force in FRP

$\mathrm{T}_{\mathrm{s}} \quad$ Tensile force in steel

$\beta_{1} \quad$ The ratio of the depth of equivalent rectangular stress block to the depth of neutral axis

$\varepsilon_{b i} \quad$ Strain level in the concrete substrate at the time of FRP installation

$\varepsilon_{c} \quad$ Concrete compressive strain

$\varepsilon_{\mathrm{ci}} \quad$ Initial strain in extreme compression fiber

$\varepsilon_{\mathrm{cl}} \quad$ Additional strain in extreme compression fiber after strengthening and loading

$\varepsilon_{\mathrm{cu}} \quad$ Maximum usable compressive strain in concrete

$\varepsilon_{0} \quad$ The corresponding compressive strain at the compressive strength

$\varepsilon_{\mathrm{fd}} \quad$ Debonding strain of externally bonded FRP reinforcement, $(\mathrm{mm} / \mathrm{mm})$

$\varepsilon_{\mathrm{fe}} \quad$ Effective strain level in FRP reinforcement; strain level attained at section failure

$\varepsilon_{\text {frp }} \quad$ Strain level in FRP reinforcement

$\varepsilon_{\text {frpu }} \quad$ Strain in FRP at the point of incipient rupture

$\varepsilon_{\text {frpl }} \quad$ Additional strain in extreme tension fiber after strengthening and loading 
$\varepsilon_{\mathrm{fu}} \quad$ Ultimate rupture strain in FRP reinforcement

$\varepsilon_{\mathrm{s}} \quad$ Strain level in steel reinforcement

$\varepsilon_{\text {sy }} \quad$ Strain corresponding to the yield strength of steel reinforcement

$\varepsilon_{\mathrm{si}} \quad$ Initial strain in steel reinforcement

$\varepsilon_{\text {sl }} \quad$ Additional strain in steel reinforcement after strengthening and loading

$\sigma_{\mathrm{cu}} \quad$ The maximum compressive strength

$\rho_{f} \quad$ FRP reinforcement ratio

$\rho_{s} \quad$ The ratio of non-prestressed reinforcement

$\psi_{f} \quad$ Additional FRP strength-reduction factor 